\title{
Connecting Nautical Tourism and Agro-food Industry as a Way to Boost Competitiveness and Sustainability of Mediterranean Destinations. The Case of Cambusa Project
}

\author{
By Gavino Balata*, Veronica Camerada ${ }^{ \pm}$Enrico Panai*, \\ Gavino Mariotti ${ }^{\star} \&$ Alessio Tola
}

\begin{abstract}
Nautical Tourism in the Mediterranean is a relevant source of revenue for the involved territories. Nautical destinations are geographical hubs capable of hosting boats and vessels. In turn, these capabilities provide both technical services and tourism-related services to the visiting yachtsmen and to the residents. Nautical destinations can be viewed as gateways to the inner or internal areas bordering the coastal areas. This access occurs provided that there are sufficient links between the offer of goods and services of the inland (agro-food products, cultural, and natural attractions and connected services) and the potential users or customers which reach the area from the sea. The Cambusa project addresses the need to establish such links. There are several means through which this project can facilitate these connections. For example, by leveraging on the attractiveness of the maritime activities, supporting the access to high quality, locally produced traditional food and fostering the connection between coast and internal areas to boost competitiveness of both maritime business and agro-food companies of the rural areas. The paper describes the approach used to develop the project and define its strategy by the means of an innovative combination of participative policymaking and lean start-up methodologies and techniques. The study result is the definition of a best practice which allows two different economic sectors to create and implement a joint territorial strategy with shared goals in order to achieve better performances.
\end{abstract}

Keywords: Nautical Tourism, Traditional Products, Lean Start-up, ECommerce, Microenterprises, Competitiveness, Blue Growth, EuroMediterranean Region.

\section{Introduction}

Sustainability is a classic problem in tourism studies (Butler 1991, Briguglio et al. 1996, Saarinen 2006). Recently, further actions have taken by the European Union interconnecting sectors to improve sustainable destinations and helping academic research and guide investments in the blue economy. Going beyond

\footnotetext{
*Research Fellow, Department of Humanities and Social Sciences, University of Sassari, Italy. ${ }^{ \pm}$Research Fellow, Department of Humanities and Social Sciences, University of Sassari, Italy. *PhD Candidate, Department of Humanities and Social Sciences, University of Sassari, Italy. 'Full Professor, Department of Humanities and Social Sciences, University of Sassari, Italy. ₹rofessor, Department of Humanities and Social Sciences, University of Sassari, Italy.
} 
the green economy, the blue economy aims to create sustainable ecosystems to enhance more rentable and greener local economies. In this perspective, The 2018 Annual Economic Report on EU Blue Economy claims that nautical tourism has received ample support from the European Regional Development Found. In fact, as already declared in 2017 in the Report on the Blue Growth Strategy Towards more sustainable growth and jobs in the blue economy, the EU "responsibility today is to make sure that maritime economic development leads to a sustainable and competitive blue economy". However, while data from several reports as the 2017 Commission Staff Working Document on Nautical Tourism suggest that in the Mediterranean area the nautical tourism is a fast-growing sector, evidence shows that the near inland agro-food small business industry is characterized by a dense environment of small and micro enterprises which showcase a reduced operational capacity and little or no international activity. This evidence supported the idea that greater efforts were needed to ensure a connection between inland agro-food industry and the nautical tourism sector. In this context, this paper aims to introduce a project designed to highlight the economic potential related to the yachting sector for the economic growth of the inland: the Cambusa project.

Cambusa is the Italian word for galley, the kitchen and cooking apparatus of a boat. The title of the project intended to highlight the relation between nautical tourism and local food. Nautical destinations are geographical hubs capable of hosting boats and vessels and provide both technical services and tourism-related services to the visiting yachtsmen and to the residents. Nautical destinations can be viewed as gateways to the internal zones bordering the coastal areas (Bizzarri and La Foresta 2011, Kovacic et al. 2016). However, this view is provided that there are sufficient links between the offer of goods and services of the inland (agro-food products, cultural and natural attractions, and connected services) and the potential users or customers which reach the area from the sea (Jolić et al. 2011, Mikulić et al. 2015).

The Cambusa project is an EU funded initiative whose aim is to foster the connections between the coast and internal areas and boost competitiveness of both maritime business and agro-food companies of the rural areas. The project started on March 2018 and it will close on February 2021. The aim is to highlight the importance of a European project to develop local areas, as already shown in the past in other areas such as the case of the Southern Baltic area (Hącia and Łapko 2017).

The final goal of the project is to leverage on the large number of nautical tourism practitioners and on the higher spending capacity shown by this type of consumers. This spending capacity could be extended to support small and micro-enterprises operating in the food sector with high quality traditional products that are normally not sold in large quantities. The purpose of the study is to describe the methods and the process used to develop the Cambusa project from the design phase to the implementation of the activities. The relevance of the study is given by the analysis of the combined approaches used to determine and implement a set of actions (building a dedicated quality brand, create an ecommerce platform and manage the related logistics, build a coordinated 
communication strategy and a viable business model to sustain and expand the activities in the future) aimed at reaching the project objective and preventing failure.

This paper begins by describing the design process of the project Cambusa and what kind of approaches have been used to set it up. It will then go on to show the next steps and the need for further investigation in order to expand our understanding of how the agro-food industry can be interconnected to the nautical tourism.

\section{Literature Review}

This study draws its theoretical bases from diverse disciplines as geoeconomics, blue economy and blue growth, tourism-related economics and marketing. The Euro-Mediterranean area is characterized by an extraordinary territorial diversity. For instance, the area represents a macro geographical region, which corresponds to a complex geo-economic mosaic and multiple geopolitical models (Prezioso 2015). For some researchers, this complexity leads to the hypothesis that the Mediterranean area can incorporate more macro-regional entities (Cusimano and Mercatanti 2018). Similarly, for all scholars, the region represents a real challenge in terms of socio-economic growth and development.

In this research, we explore possible spatial aggregations to overcome the gap of growth and development that has been generated in two main instances. This study will consider spatial aggregations within the Mediterranean region and between geographical areas. We, therefore, observe areas with specific territorial features including remote and peripheral territories, widely studied by the European Observation Network for Territorial Development and Cohesion in 2010 and 2013. For example, these peripheral territories could encompass small islands and internal or inner areas. These areas were selected as different distance, commuting, dissimilar access to the labour market create strong limits to growth to participate in the European debate on the development of territories with geographical specificities, stimulated by the Lisbon Treaty (ESPON EUROISLANDS 2013).

The paper investigates the strengths and potentialities of development of insular, sparsely populated coastal areas, and internal territories connected to them. In addition, this study considers the advances for the hypothesis of a possible revival of these areas through the blue economy, that according to the World Bank (2017) identifies the sustainable use of marine and maritime resources as the strategic tool for long-term economic growth.

The Mediterranean region seems to be the ideal place to develop the virtuosities connected to the blue economy. According to Prezioso (2015: 95), "the territorial diversity of the Mediterranean - measured in terms of real and potential territorial capital - emerges as a relational asset that is already the bearer of blue and green values useful for redesigning the land-sea relationship". However, complex as it may be, the variety of scenarios in the EuroMediterranean area is, in fact, an added value. Thanks to the implementation of links between inner/internal geographical and coastal areas, which can be found 
considerably in the Mediterranean basin (Figure 1) there are potential development models to consider. For example, would be possible to achieve sustainable and tailor-made development models, directly inspired by the Blue Growth Strategy of the European Union (European Commission 2012). In fact, the recommendation of the Directorate-General for Maritime Affairs and Fisheries (known as DG MARE) is to explore the growth options in the maritime sector and contribute to the achievement of the Europe 2020 goals through the Blue Growth strategy. The Directorate accomplishes such efforts by securing jobs and growth in coastal areas, with positive effects also in the internal areas.

Figure 1. "Hot Spots" of Land-Sea Interactions

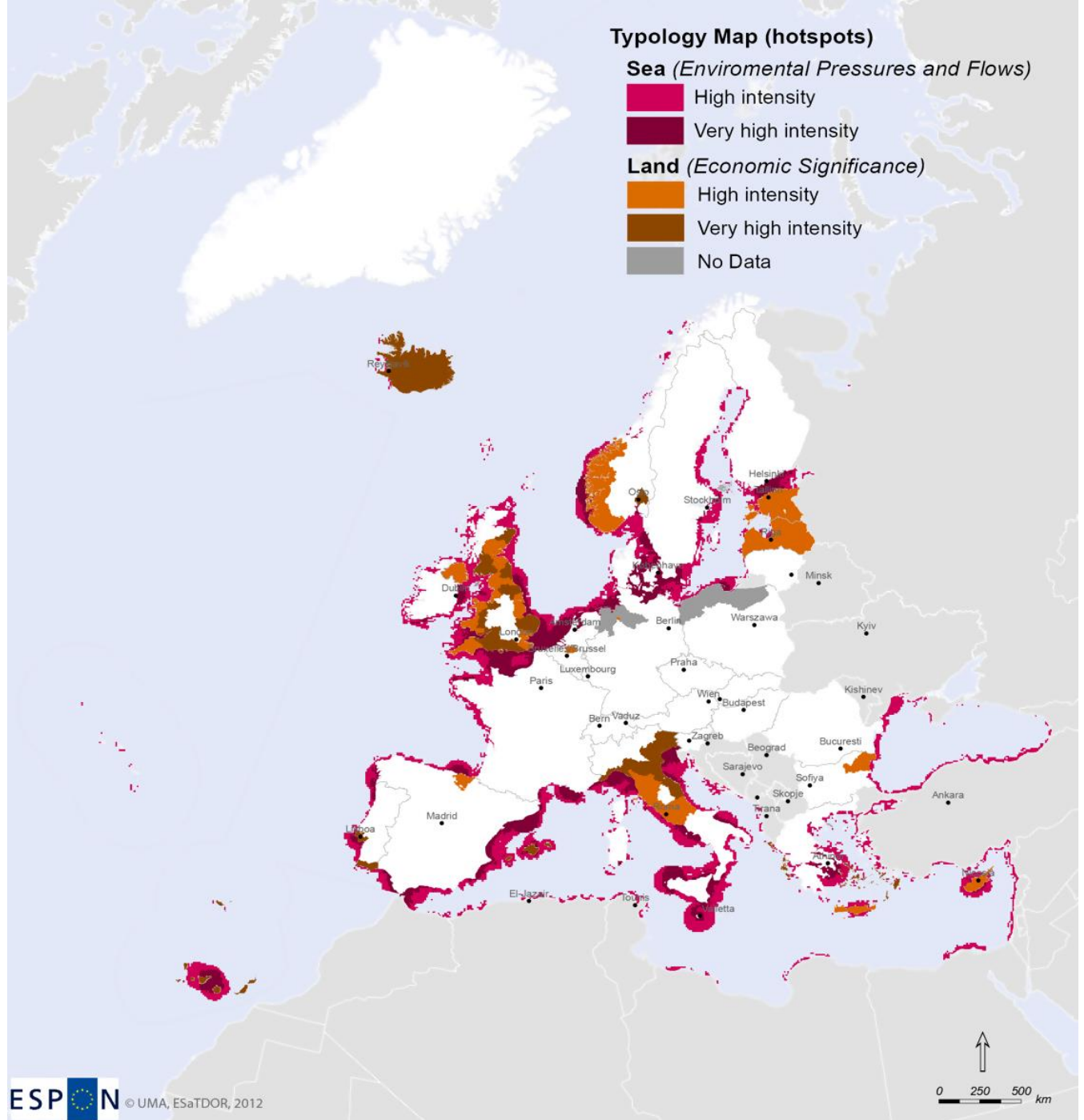

Source: ESPON, ESaTDOR - European seas and Territorial Development, Opportunities and Risks (2013).

Indeed, evidence suggests that the Blue Economy is already among the most important factors for development of sustainable economies in the European Union with particular reference to the Mediterranean regions. In general, the EU Blue Growth involves 5.5 million employees and generates $€ 500$ billion of gross 
added value a year (European Commission 2019). As part of EU's Blue Growth strategy, the coastal and maritime tourism sector has been identified as an area with special potential to foster a smart, sustainable and inclusive Europe. Specifically, as reported in the Coastal and Maritime Tourism document by the European Commission in 2019, costal and maritime tourism generates $€ 183$ billion in gross value added. According to the Commission Staff Working Document on Nautical Tourism of the European Commission (2017: 3), "the nautical tourism activity is concentrated in the services sector, which generates approximately $59 \%$ of its economic output, and on the Mediterranean coast".

It is important to note that in recent years, with regard to boat moorings alone, the Mediterranean has become the landing point for over $18 \%$ of them (Buono and Soriani 2012).

This performance is linked, not only to the climatic and environmental conditions of the area, but also to the improvement of port infrastructures. In turn, these infrastructures have made possible an important expansion of the cruise business. Given, these activities, many port cities have been regenerated. Ergo, it is assumed that by proceeding along this line of development, it is possible to encourage the development of the inner areas. This development could stem from reinforcing the interconnections between marine and land areas. In this contest, ports take a crucial role in the sea-land connection. As shown in the map published by Espon in a working paper in 2017 (Figure 2), port areas in the EU can provide services to internal territories reaching a population that varies from 5 to 20 million people (ESPON 2017). At the same time, accessibility to the sea guarantees access to consumer goods for the island regions, as well as the expansion of the market segment into which local products can be placed.

By embedding the economy of the internal areas with the economy generated by the maritime sector, nautical tourism can be the right tool to raise the competitiveness of those extremely vulnerable geographical areas, that today face complex development challenges. Therefore, it should be compulsory to rethink and redesign the strategy of the territorial development of the Mediterranean area. In doing so, this analysis would lead to adopting a more geographical-functional approach inspired by the EU Blue Growth strategy (Coronato 2018).

The functional approach pushes towards the search for new spatiality, which can become the object of a different planning oriented to the co-development of close areas (Camerada et al. 2019).

In order to study a functional development strategy for the analysed territories, it is advisable to provide a definition of internal and inner areas to scan the opportunity to link them to costal territories. According to the Italian research group coordinated by Prezioso that operates within the PRIN (Progetti di Ricerca di Rilevante Interesse Nazionale) with the theme "Territorial Impact Assessment of territorial cohesion of the Italian regions" inner areas can be defined as territories "located or occurring within or near a centre" (Prezioso 2019: 142). On the other hand, internal areas are territories geographically distant from a growth engine and service centres. In the first case, these are areas in decline and are typically close to cities or adjacent to metropolitan regions. These are areas often affected by the industrial transition that occurred 
in recent history (Scrofani et al. 2019). In the second case, these are territories that have not been able to compensate their distance from the centre by exploiting their territorial capital. In both cases, they are areas that today play a marginal role in socio-economic development. In essence, these are territories marginal, not only in geographical position, but also distant from the average economic performance of the regions to which they belong (Pagetti and Ietri 2019).

Figure 2. Hinterland Accessibility of Main Ports

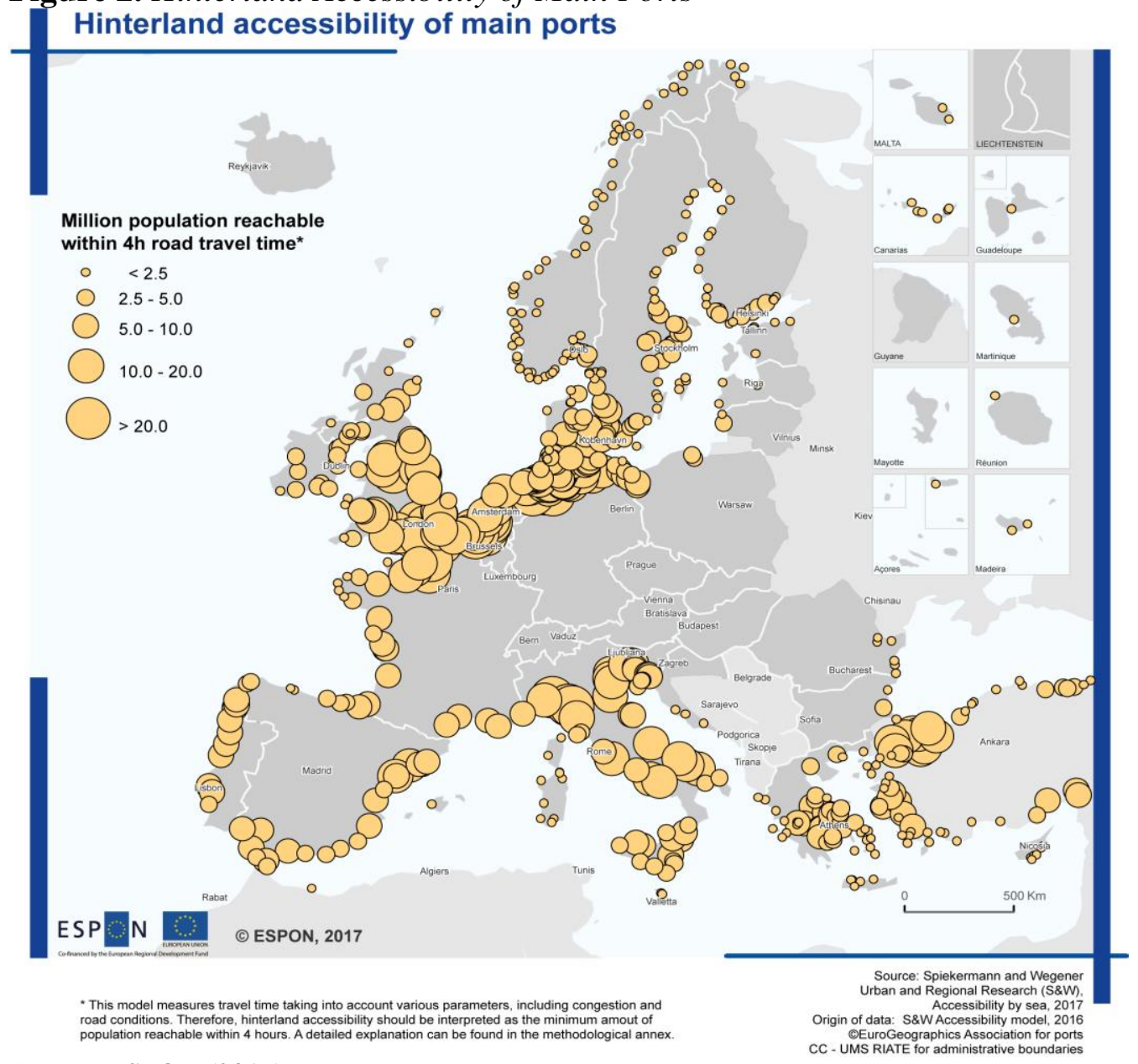

Source: ESPON (2017).

Structural delays and low resilience to economic crises are common in these areas as well as in island territories. The limits to the development of the inner areas are comparable to those of the island regions. In fact, "islandness, peripherality, and dependence are considered to constitute the elements of the concept of insularity; which relates to the wider spectrum of specific conditions impinging upon human development in island territories" (ESPON GEOSPECS 2013: 63). Looking at the island, "the main characteristics of insularity are a small size of population and limited access as well as limited resources and remoteness from the European or national centre. Other factors include isolation and low accessibility, unique cultural heritage, and rich but fragile natural 
environment" (ESPON GEOSPECS 2013: 63). Therefore, islands and internal/ inner areas in Mediterranean region are often affected by limits regarding accessibility, low access to services, and critical population structure. In short, we can define these geographic areas as less favoured in the territorial growth process. This impact could occur as these areas incorporate both for geomorphological conformation and because they are extraneous to the development processes, prerequisites for poverty and social exclusion. In the territorial planning, it is fundamental to promote and exploit the "territorial capital" (Camagni 2009), which distinguishes specific territories. The peculiarities of the multiple geographic realities existing in the European space can become a strength, even when they seemingly assume the connotation of territorial handicaps. In this new approach the tools and goals of polycentric and inclusive development are determined on the basis of regional realities through an evidence-based approach (Camerada and Podda 2017). Starting from this perspective, it is possible to determine the tools and goals of polycentric and inclusive development. These tools could be obtained based on regional realities and diversity through an evidence-based approach and by exploiting the set of territorialized capabilities through which it is possible to generate collective competitive advantages (Dematteis and Governa 2005). Therefore, the European Grouping on Territorial Cooperation (ESPON EGTC 2017) already started to investigate and empower the land-sea interactions.

From a more theoretical point of view, the project develops through the process of glocalization. In fact, the development of virtual spaces in cyberspace has enhanced the geographical dimension thanks to the interpenetration of global and local, virtual, and real. According to Bailetti et al. (2018), glocalization processes can expand from a bottom-up approach (globalization of the local), from a top-bottom (localization of the global) and horizontally (local migration and global dissemination). In fact, every phase of the project shows the consistency of this axiomatic characterization.

\section{Methodology}

The purpose of the study is to describe the methods and the process used to develop the Cambusa project from the design phase throughout the first year of implementation.

The methodology used is a descriptive analysis of the activities conducted and it is divided in two steps, preceded by a short resume of the project goals, partner network and main activities.

The first step of the descriptive analysis is dedicated to the project design phase. This first aspect describes the initial status and the identified problems through SWOT (Strengths, Weaknesses, Opportunities, and Threats) analysis. In addition, this step also illustrates the stakeholders' role in defining a solution, the choice of the specific objectives and of the tools used to meet set goals.

In this phase, the potential failure threats in terms of: 
- Problem-solution mismatch.

- Supply side operators (Harbours, agro-food companies, local communities) involvement.

- Users involvement.

and are matched by appropriate measures adopted by the project partners and described in the paper.

The second step of the analysis focuses on the implementation phase including the use of surveys, focus groups, and mapping tools. The initial steps of the project are explained and the use of participative activities and of lean start-up methodologies (Ries 2011) is highlighted.

Qualitative and quantitative research designs were adopted to provide a better understanding of the phenomenon.

This type of analysis provided the project partner with the needed insights regarding the available products in the area and the business needs of the local food sector. Likewise, the data also establishes a quantitative framework for detecting the nautical tourists' interest.

The paper draws from the analysis a set of conclusions and recommendations (lessons learned) which could help other decision makers to plan future actions in the same field.

\section{Results and Discussion}

\section{Description of the Project}

The Cambusa project involves 2 local entities (the municipalities of Bonifacio, Corsica, and Capoliveri, Tuscany), 3 business associations of nautical operators (Assonautica Nord Sardegna, Assonautica La Spezia, and France Stations Nautiques) one university (Sassari), and the lead partner, the Chamber of Commerce of Sassari. The project was successfully submitted for funding to the second call for projects of the Interreg Maritime cooperation programme of the European Union.

The Cambusa project's objective is to create a sustainable e-commerce platform supported by an integrated logistics system. Through this method, yachtsmen and nautical tourism practitioners can purchase high quality traditional food products (often made in the internal territories) and have them delivered directly to the chosen harbour. The products will be identifiable thanks to a quality brand, whose requirements are designed in collaboration with the local enterprises. The brand not only provides for the identification of the products but also guarantees that the technical features that ensure safe storage and use aboard vessels, especially medium or small sized ones. The technical features are mainly related to the packaging solutions used, which must be capable of preserving the sensory characteristics of the products in the maritime environmental conditions (resistance to humidity, saltiness etc.). 
At the same time, the project will provide the harbour or marinas management companies with an additional innovative service, thus boosting their competitiveness and attractiveness. Moreover, the project aims to enhance the potentiality of the nautical tourism in a variety of manners. For instance, these enhancements could be accomplished by: 1) developing a new digital service integrated to the marinas' web interfaces in order to increase the quality of web communication and the territorial land-sea interconnection (Benevolo and Spinelli 2018). Other methods include: 2) integrating the philosophy of privacy by design and security at the very beginning of the project (as indicated by the European General Data Protection Regulation, GDPR). This incorporation serves to strengthen the general competitive profile of tourist destinations that develop in port contexts. Moreover, these profiles should be established according to the importance of the cybersecurity in the tourism market (Magliulo 2016, Panai 2018) and its geographical influence (Panai et al. 2019).

The key point and value-added feature of the project is its focus on micro/ small businesses. Normally, these businesses are excluded from other commercial opportunities although their products are highly interesting for this specific category of tourists. According to the idea that consumer behaviour may influence new opportunities (Cohen et al. 2014), the underlying hypothesis of this paper is that nautical tourists are involved in "exploration" and "discovery" of new experiences (including culinary experiences) more than the average tourist. These tourists represent a niche of consumers that is deeply interested in specific products. Likewise, these consumers enjoy searching for specialties that are deeply connected to the regions they visit during their trips.

\section{$\underline{\text { Step 1: Project Design Phase }}$}

Project Cambusa is inspired by a similar initiative called "la Cambusa di Assonautica". Assonautica is the main business organisation of the nautical sector in Italy and its North Sardinian Branch is one of the members of the partnership currently managing the grant. Both projects start by defining the problem from the agro-food companies' point of view. The quality agro-food sector in Italy is one of the pillars of the national economy. Italy is the first EU country for PDO, PGI and TSG certifications (269), followed by France (219) and Spain (180).

There are over 56,600 agro-food companies in Italy, employing over 385,000 workers (Federalimentare 2018). Indeed, the total turnover of the sector is estimated in $€ 140$ billion per year. The agro-food sector is made mainly by small or micro-enterprises and are often family-based. According to the Italian National Institute of Statistics ${ }^{1}$, in 2017 these companies made up for $98.4 \%$ of the total number of enterprises and employ $62.4 \%$ of the workers. As a result, these companied generate approximately $40 \%$ of the total turnover.

While the overall performance of the sector increases steadily, the smaller businesses struggle to keep up with the sector's average. This limitation is

\footnotetext{
${ }^{1}$ ISTAT. https://www.istat.it.
} 
especially significant in terms of internationalisation and export results (ISMEA 2018).

The SWOT analysis (Table 1) executed in the design phase of the project, in collaboration with the project partners, identified the following issues:

Table 1. SWOT ANALYSIS

\begin{tabular}{|c|c|c|}
\hline & Strengths & Weaknesses \\
\hline $\begin{array}{l}\text { For Nautical } \\
\text { Destinations }\end{array}$ & $\begin{array}{l}\text { - Involved in networks } \\
\text { - Environmental attractiveness } \\
\text { - Strategic position in the } \\
\text { Mediterranean } \\
\text { - Different targets } \\
\text { - Inland territories rich in } \\
\text { traditions } \\
\text { - Large availability of mooring }\end{array}$ & $\begin{array}{l}\text { - Lower-level of services available } \\
\text { - Little cooperation with internal } \\
\text { areas } \\
\text { - Sector-Oriented business model } \\
\text { - User retain }\end{array}$ \\
\hline $\begin{array}{l}\text { For Local } \\
\text { Agro-food SMEs }\end{array}$ & $\begin{array}{l}\text { - High number of quality products } \\
\text { - Sustainable production } \\
\text { - Traditional productions } \\
\text { - Large number of companies }\end{array}$ & $\begin{array}{l}\text { - Small dimension } \\
\text { - Weak e-commerce capabilities } \\
\text { - Low export/sales capacity } \\
\text { - Reduced operational capacity }\end{array}$ \\
\hline & Opportunities & Threats \\
\hline $\begin{array}{l}\text { For Nautical } \\
\text { Destinations }\end{array}$ & $\begin{array}{l}\text { - Capitalise on the links between } \\
\text { coast and interior areas } \\
\text { - Increase services available }\end{array}$ & $\begin{array}{l}\text { - Competition from other Med areas } \\
\text { (East, North Africa) }\end{array}$ \\
\hline $\begin{array}{l}\text { For Local } \\
\text { Agro-food SMEs }\end{array}$ & $\begin{array}{l}\text { - Renowned agro-food heritage } \\
\text { - Appeal of the Mediterranean diet } \\
\text { as a healthy lifestyle } \\
\text { - Appeal for sustainable (non- } \\
\text { industrial), proximity production } \\
\text { - Differentiate sales channels }\end{array}$ & $\begin{array}{l}\text { - Presence of strong players } \\
\text { (catering companies and organised } \\
\text { retail networks) } \\
\text { - Incomplete transition towards } \\
\text { digital operations }\end{array}$ \\
\hline
\end{tabular}

The main points identified among the strengths are the networking capabilities and the overall attractiveness of the nautical destinations in the Mediterranean areas. The routes connecting the territories of the project are strongly connected and populated by yachtsmen. The agro-food SMEs can leverage on the high variety of quality products. It should be noted that these products are manufactured according to traditional methods. The proximate inland areas of the cooperation area are densely populated with a high number of agro-food SMEs.

The combination of high numbers of possible players and a large variety of available products of renowned quality is an asset on which a development strategy can be built upon.

On the other hand, the weaknesses of the nautical destinations are linked to the high investments required to maintain competitiveness. Nautical tourism is growing in other areas of the Mediterranean Sea, which leads to an increase of competitiveness from other regions. Agro-food SMEs, especially the familyowned businesses, experience difficulties in adopting new business models and to adapt to technological change. This weakness, combined with the higher capabilities shown by their direct competitors (supermarket chains, catering providers), is leading these companies to underperform. 
In this framework, the project partners identified the following problemsolution scheme (Figure 3).

Figure 3. Problem-solution Fit Scheme of the Cambusa Project

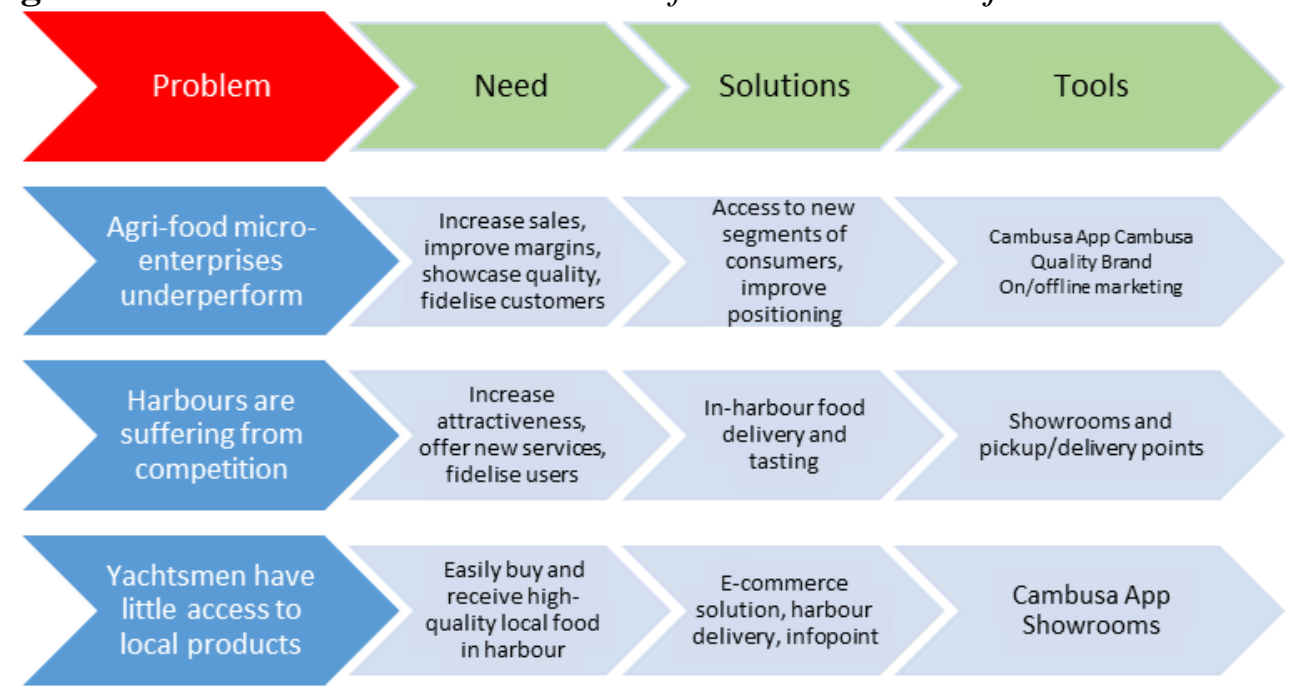

The elements of the problem-solution fit scheme were identified during the initial phase of the project using official data provided by the Chamber of Commerce and by the nautical companies' associations.

The initial version of the Cambusa project contemplated only the setup of exposition points in the harbours. In this case, the yachtsmen could know more about local products and eventually purchase them autonomously.

The recent availability of mobile and e-commerce solutions made it possible to integrate these components within the initial version of the Cambusa. The revised version of the project maintained the element of the exposition points (showrooms) while upgrading the logistic support features to sales with a centralised system and an e-commerce "app". The showrooms become, thus, not only a showcase of the local production or an information point, but also a temporary storage facility and picking station. Consequently, the orders are delivered by the producers, are assembled, and then taken to the final client. A coherent marketing and communication strategy was then introduced as a specific component of the project. The intent was to ensure that both, the institutional communication requirements (mandatory for EU-funded projects) and the promotional activity related to the Cambusa system, could reach its target. The marketing strategy is also linked to another pillar of the project, the Cambusa Quality brand. This brand will group under a series of technical specifications all of the products available on the Cambusa app.

\section{Step 2: Implementation Phase}

After the project start-up phase, in March 2018, the activities related to the Cambusa Quality brand regulation drafting were started by the University of Sassari. The university developed a holistic strategy aimed at acquiring 
information on each aspect of quality brand building. In this regard, this aspect involved both supply and demand side of the market (yachtsmen, food producers, harbour managers, and local business associations). The university, in collaboration with Assonautica North Sardinia, developed:

- A questionnaire on the features of the Cambusa system. This tool was administered to yachtsmen in all the regions involved in the project (402 interviews).

- A focus group structure used to organise meetings with the local producers in each region (minimum 4 meetings per region).

- A mapping tool used to collect, per each region, the most relevant and representative local products (cheeses, wines, olive oil, honey, bakery products, and cured meat) which the partners wished to introduce in the Cambusa system.

In this phase of the project, the project partners mapped all the most relevant and representative traditional products in each region. The aim of this mapping effort was to share a common knowledge base among the partners. As a result, all parties could understand which products could be introduced in the Cambusa system and what kind of requirements should be integrated in the Cambusa Brand regulations. The mapping activity resulted in approximately 100 product fiches. These findings included information on type of product (e.g. bakery, wine, meat or fish-based preparations) and description of the product manufacturing process. In addition, the mapping effort comprised references to the traditions and history of the product, packaging requirements (vacuum, refrigeration, type of container, size). The analysis also highlighted the presence of previously-obtained EU certifications of origin such as Protected Designation of Origin (PDO), Protected Geographical Indication (PGI), or other local certifications as Label Rouge for France and Prodotti Agroalimentari Tradizionali (PAT) for Italy.

Through the analysis we grouped 9 types of products:

- Wine and alcoholic beverages

- Mineral water and non-alcoholic drinks

- Dairy products

- Confectionery products

- Pasta, bread, and baked goods

- Meat, vegetables, and fish preserves

- Delicatessen and sausages

- Honey and oil

- Other typical local products

Once the results of these three actions were shared among the partners, the university created a draft of the brand regulation guidelines with specific sections for each category, subject to a two-step validation by the partners. 
These guidelines contained the award procedures, requirements and points, duties, and rights of the applicants.

\section{Participative Approach and Lean Start-Up Strategy}

The risks connected to activities, such as the ones included in the Cambusa project, are similar to those sustained by digital entrepreneurs. Failure to achieve adoption on the users' side of the proposed solution is one of the main concerns of the project team.

This fact stimulated the project team to adopt practices based on the lean startup methodology described in Ries (2011). The lean start-up method "provides a scientific approach to creating and managing start-ups and get a desired product to customers' hands faster". In this case, the term start-up is referred to new companies. For the purpose of this study, the term customer is used to refer to the final users of the project. The lean start-up is based on the continuous iteration described in Figure 4.

The project team decided to apply the methodology to the project as a whole, to the brand regulation drafting, to the app and logistics platform design and testing and to the final activity which intends to develop a viable business and organisational model capable of keeping the project active after the EU funding period is over.

Figure 4. The Lean Start-up Cycle

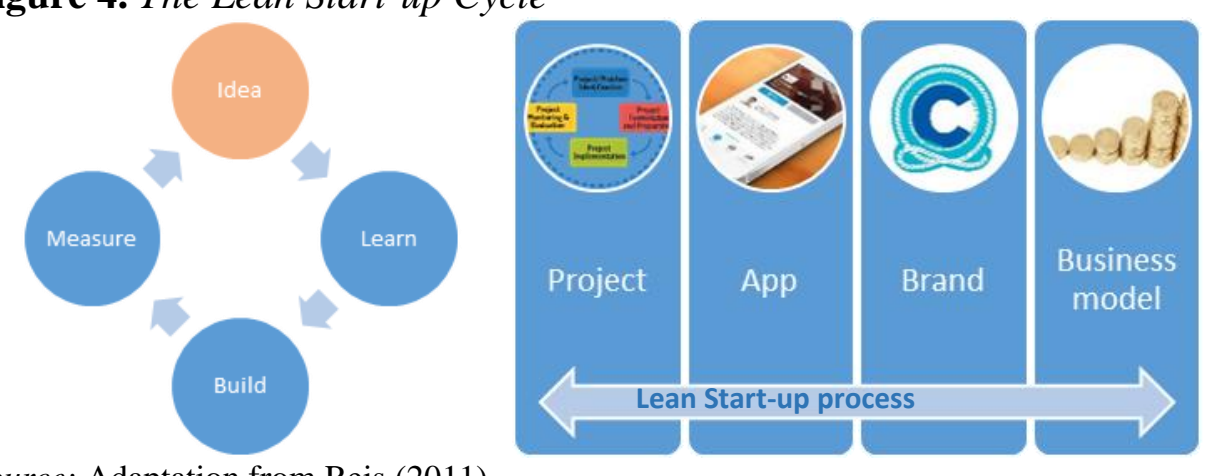

Source: Adaptation from Reis (2011).

The First Cycle Took Place during the Initial Version of the "Cambusa di Assonautica"

The concept was only partly validated and struggled to scale up given some technical elements, such as an adequate logistics platform, a coordinated marketing strategy, a commercial network, were not yet developed or integrated in the model. The second cycle is running at the present time. The idea was developed and tested thanks to the surveys and the focus groups. We could also hypothesize that, being Cambusa an EU-funded project that undergoes strict evaluation processes by third-part experts, that there was a theoretical pre-testing phase of the project's viability carried out by the evaluators. In fact, EU projects are strictly evaluated by a committee of experts. This allows to presume that a project awarded funding has already undergone an independent screening aimed to ascertain its reliability 
and the capability of the partners to deliver the expected results described in the technical proposal.

Regarding the testing or of the initial idea, the main features of the Cambusa e-commerce product were validated through a survey issued to over 400 yachtsmen in the area. The questionnaire contained a profiling section. The following two sections were dedicated to describing which type of agro-food products and what kind of service components the future users could consider of interest.

The profiling section investigated on the characteristics of the sample both in general terms as age, sex, place of residence, and technology awareness (is the level of familiarity and expertise of the user related to the use of technology). This section also included questions regarding the specific traits of the yachtsmen such as the type of vessel, size, and frequency of use. The section also included survey items on the consumption behaviour and desired contents of an app for yachtsmen.

The sample obtained counted 402 respondents ( $81 \%$ male, $19 \%$ female), with an average age of 52.4 years. Sailboat users are $59.4 \%$ of the sample, while the rest are motor boat users. The average size of the vessels is 13 meters $(\sim 43 \mathrm{ft}$.) with engine-powered boats showing a slightly larger size $(14.37 \mathrm{~m} ; \sim 47 \mathrm{ft})$ compared with sailboats $(12.25 \mathrm{~m} ; \sim 39 \mathrm{ft})$.

The surveys were collected during summer 2018 in Sardinia (38.80\%), Liguria (24.9\%), Tuscany (9.6\%) and Provence-Alpes-Côte d'Azur (26.7\%) regions, as shown in Figures 5 and 6.

Figure 5. Map of Europe with the Regions of the Investigation Survey area

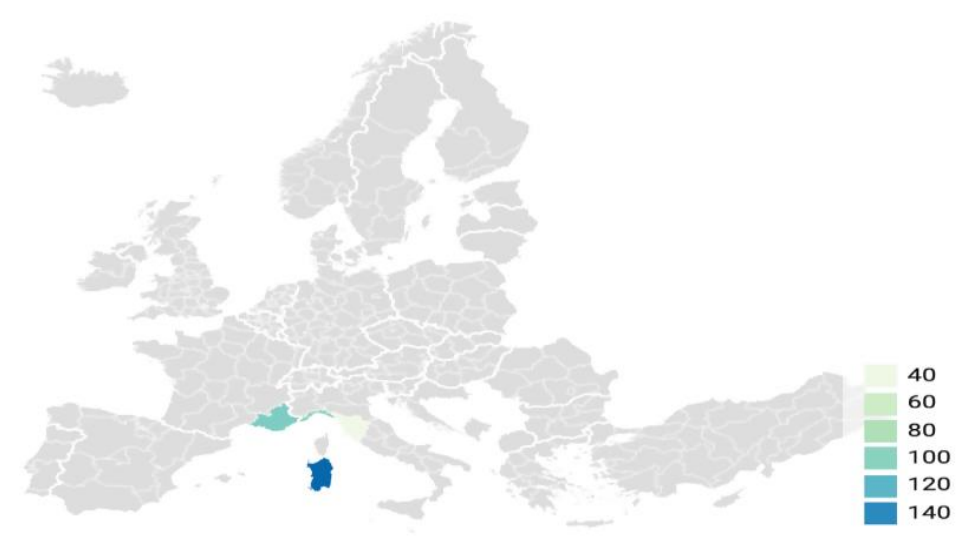

Source: Elaboration by the authors. 
Figure 6. Map with only the Regions with Data

\section{Survey area}
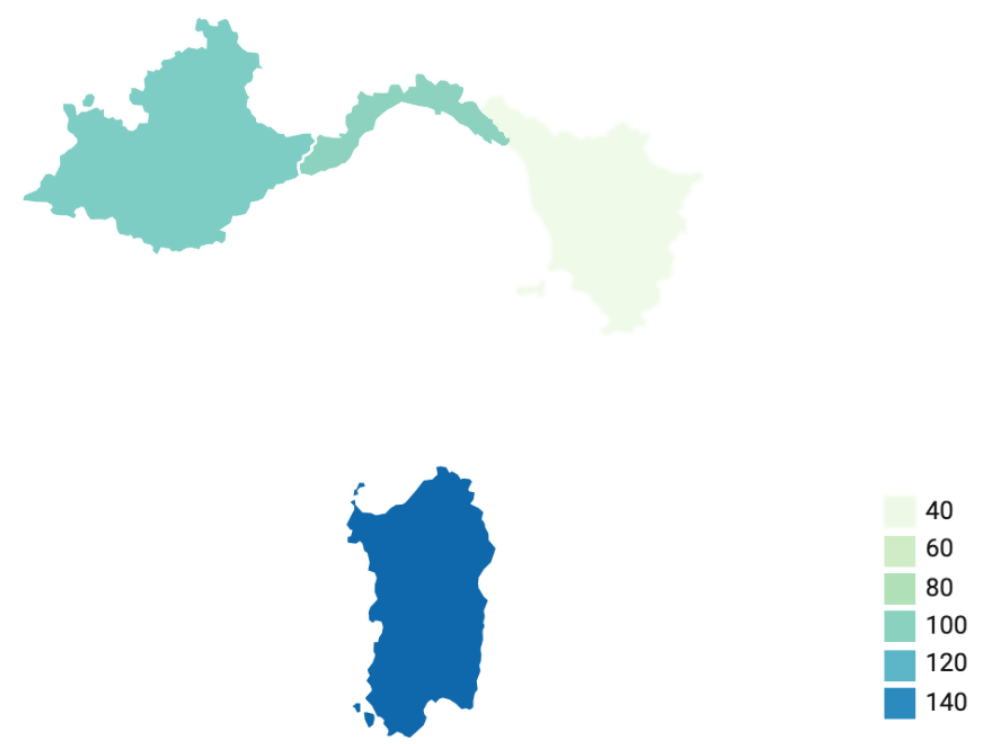

Source: Elaboration by the authors.

The product of section of the survey contained 5-point Likert-scale items on the kind of desired food products. This section included considerations in terms of price and type of food (generic, traditional, high quality). In a similar fashion, the section dedicated to the service attributes evaluated the interest of yachtsmen towards the other features of the Cambusa system. These features included showroom facilities, in-harbour delivery, and additional content (such as information on cultural events or points of interest). Finally, the service section included also questions on the type of payments and on the willingness to pay an extra charge to use the Cambusa system.

The preliminary results of the survey confirmed the fitness of the initiatives with high levels of potential adoption. Yet, there were some differences found in the samples. For instance, the different consumer behaviour of small boat and large vessels owners/users, are addressed with an appropriate marketing and communication strategy.

Participation of external stakeholders, apart from the project partners, is key to avoid project failure. The building of the Cambusa Brand regulation guidelines was achieved through a participative method (focus groups) organised in each territory. The purpose of using this kind of techniques was to prevent the partners from defining the brand guidelines in a way that did not take into account the companies' opinions. Adoption of a quality brand is often a stressful procedure for companies that, as in the case of agro-food, are already subject to a large number of binding regulations. Negotiating the technicalities with the companies by asking their representatives which requirements could improve the customer satisfaction proved to be the way to create regulations with a shared vision. This vision resulted in an appropriate level of strictness and a higher applicability. Furthermore, inviting the producers in the early phase of the project showed 
positive effects in terms of ownership and participation to the project activities. As a result, this effect contributed to build a strong support base among the companies involved.

\section{Conclusions}

The study is part of the European political debate on the development of territories with geographical specificities. Specifically, the study investigated the competitive opportunities of isolated areas rich in unique resources. Looking at the Mediterranean area, the opportunities for growth in this region are expanding by using the potential of this in terms of Blue Growth. The relationship between land and sea identifies the strategy for bringing out the potential of the territories in question. This relationship can be facilitated with the incorporation of tools provided by technological innovation that capable of interconnecting places and territorial capital.

To this end, the Cambusa project is presented here, an EU founded project aimed at developing the interaction between nautical tourism and agro-food companies of the internal areas. The first phase helped to define the project's needs of the agro-food companies. During the second phase, this study employed survey methodology to investigate the feasibility of the project. By the end of the survey period, data had been collected from more the 400 yachtsmen and the team is now investigating the collected data. Despite its practical nature, this study will offer some insight into attitude of purchase of nautical tourists and any possible geo-economic impact. Regarding the approach used to define and implement the project activities, the involvement of all the concerned actors, through a multi-level approach to the stakeholders, proved to be effective in terms of participation and sense of ownership developed by the companies and the local entities involved.

The future developments of the project, which will finish in 2021, will be subject to analysis in order to understand the impact of the adopted approach in terms of final performance. The evaluation of the performance will be based on a set of indicators such as number of transactions, overall generated turnover, and additional turnover generated for the single participant. Other aspects include quality levels perceived by the users in terms of satisfaction for the additional services provided, satisfaction of the harbour operators regarding the effectiveness and attractiveness. Lastly, social media performance analysis could also be part of the evaluation. Lean start-up methodologies include such indicators in their implementation as a tool to steer the project towards the best final results. The importance of sharing the results of the performance indicators and, more generally, using the common base of information to co-design the development strategies with a collaborative approach, is the key of the success of initiatives like Cambusa. These characteristics are recognised by the partner organisations' representatives. Further research should be undertaken to investigate the yachtsmen behaviour. Research questions that could be asked include the correlations between type and dimension of the boat and the consumer purchasing decision-making. Additionally, the data obtained could be used to develop maps 
of the yachtsmen routes in central-western Mediterranean in order to create a base of knowledge useful to determine development strategies shared by the bordering regions of the area. While this paper has drawn a set of recommendations which could help other decision makers to plan future actions in similar fields, forthcoming implementations will have a number of important implications for the local market. Briefly, future findings will have significant implications for the understanding of how the link between the inner areas bordering the coastal areas and the nautical tourism could be strengthened.

The paper's main limitations are mainly connected with the fact that the project is still in the early implementation phase. More precise data and quantitative feedbacks will be obtained at the end of the first cycle of testing of the e-commerce system, which will take place during summer 2019.

Another limitation of this study is the nature of the data that was used to define the methodology. Only the project partners have been involved in the interviews and meetings carried out to define the project activities. This could have led to a positively-biased evaluation of the project structure. External, nonbiased data, which will be collected during the last phase of the project (late 2020), will help to determine whether the positive bias hypothesis should be rejected. This last phase will include communication and networking activities to promote the adoption of the Cambusa model in other Mediterranean territories.

\section{Acknowledgements}

The authors wish to thank, for their kind collaboration, the project Partners:

Camera di Commercio Industria Artigianato ed Agricoltura di Sassari, Mr. Pietro Esposito, Mrs. Monica Cugia, Assonautica nord Sardegna, Mr. Italo Senes, Assonautica la Spezia, Mr. Romolo Busticchi, France Stations Nautiques, Mr. Bernard Faucon and Mr. Alain Auton, Comune di Capoliveri, Mr. Claudio della Lucia, Mairie de Bonifacio, Mr. Michel Mallaroni.

This study was carried out in the framework of the Cambusa Project. Cambusa is funded by the EU territorial cooperation programme INTERREG MARITIME Italy-France 2014-2020.

\section{References}

Bailetti T, Enkerli A, Craigen D, Tanev S (2018) Applying Glocalization Principles to Enhance a Cybersecurity Ecosystem of Ecosystems. Proceedings of the ISPIM Innovation Forum, Boston.

Benevolo C, Spinelli R (2018) The quality of web communication by Italian tourist ports. Tourism: An International Interdisciplinary Journal 66(1): 52-62. 
Bizzarri C, La Foresta D (2011) Yachting and Pleasure Crafts In Relation To Local Development and Expansion: Marina Di Stabia Case Study. In Coastal Cities 2019, WIT Transactions on Ecology and the Environment, vol 149.

Briguglio L, Archer B, Jafari J, Wall G (1996) Sustainable tourism in Islands and small states: Issues and policies. London: Pinter.

Buono F, Soriani S (2012) M-Mare/Sea. Mediterranean Lexicon. Geo-Italy 5 - Series published by the Italian Committee for the International Geographical Union. EUPOLIS, Rome. Società Geografica Italiana, 165-180.

Butler R (1991) Tourism, environment, and sustainable development. Environmental Conservation Volume 18(3): 201-209. London: Cambridge University Press.

Camagni R (2009) Per un concetto di capitale territoriale, in Borri D., Ferlaino F. Crescita e sviluppo regionale: strumenti, sistemi e azioni. Milano: Franco Angeli.

Camerada V, Podda C (2017) Eutopie d'Europa. Territori insulari e soft spaces nello spazio UE. In AA.VV. (a cura di): Marconi M. Stinca G., Utopie della terra, pp. 256282. Roma: Edigeo.

Camerada V, Podda C, Lampreu S, Madau C, Battino S (2019) Inner Areas/ Periferie metropolitan e differenze con le Internal Areas, Inner Areas/Periferie metropolitan e differenze con le Inner Areas, in Prezioso, M., 2019. Quale Territorial Impact Assessment della Coesione Territoriale nelle regioni italiane. La concettualizzazione del problema, pp.197-204. Bologna: Pàtron.

Cohen S A, Prayag G, Moital M (2014) Consumer behaviour in tourism: Concepts, influences and opportunities. Current Issues in Tourism 17(10): 872-909. DOI: 10. 1080/13683500.2013.850064.

Coronato M (2018) Blue economy and land sea planning: a green oriented systemic sectoral approach. Bollettino AIC 2018(164): 34-44. Trieste. EUT.

Cusimano G, Mercatanti L (2018) La strategia europea delle macroregioni. Opportunità e criticità. Geotema 57: 8-17. Bologna, Pàtron Ed.

Dematteis G, Governa F (2005) Il Territorio Nello Sviluppo Locale. Il Contributo Del Modello SLoT. Milano: Franco Angeli.

ESPON European Observation Network for Territorial Development and Cohesion (2013) ESaTDOR - European seas and Territorial Development, Opportunities and Risks. Luxemburg. ESPON \& University of Liverpool.

ESPON European Observation Network for Territorial Development and Cohesion (2013) GEOSPECS European Perspective on Specific Types of Territories. Luxemburg: ESPON \& University of Geneva. Retrieved from https://www.espon.eu/sites/default/ files/attachments/GEOSPECS_Draft_final_scientific_report_22612.pdf. [Accessed 3 March 2019].

ESPON European Observation Network for Territorial Development and Cohesion (2013) EUROISLANDS The Development of the Islands - Europeans Islands and Cohesion Policy. Luxemburg: ESPON \& University of Malta. Retrieved from https://www. espon.eu/sites/default/files/attachments/Final Report_foreword_CU-16-11-2011.pdf. [Accessed 3 March 2019].

ESPON EGTC European Observation Network for Territorial Development and Cohesion (2017) Revealing territorial potentials and shaping new policies in specific types of territories in Europe. Island, mountains, sparsely populated and coastal regions. Luxemburg: ESPON EGTC. Retrieved from file:///Users/sardusfrance/Downloads/ ESPON_Working_Paper_Revealing_territorial_potentials_and_shaping_new_policie s_3.pdf. [Accessed 3 March 2019].

European Commission (2012) Scenario and Drivers for Sustanable Growth from the Oceans, Seas and Coasts. Retrieved from https://ec.europa.eu/maritimeaffairs/publi 
cations/blue-growth-scenarios-and-drivers-sustainable-growth-oceans-seas-andcoasts_en. [Accessed 12 April 2019].

European Commission (2017) Commission Staff Working Document on Nautical Tourism. Bruxelles. Retrieved from https://ec.europa.eu/maritimeaffairs/ sites/maritimeaffairs/ files/swd-2017-126_en.pdf. [Accessed 12 April 2019].

European Commission (2019) Blue Growth Retrieved from https://ec.europa.eu/maritime affairs/policy/blue_growth_en. [Accessed 12 April 2019].

European Commission (2019) Coastal and maritime tourism. Retrieved from https://ec.eu ropa.eu/maritimeaffairs/policy/coastal_tourism_en. [Accessed 12 April 2019].

Europea Union (2018) The 2018 annual economic report on EU Blue Economy. Available at: https://ec.europa.eu/maritimeaffairs/sites/maritimeaffairs/files/2018-annual-econo mic-report-on-blue-economy_en.pdf.

Federalimentare (2018) Report Conclusivo di Monitoraggio 2017/2018 Indagine di Follow-Up. Retrieved from http://www.federalimentare.it/new2016/Aree Operative/ FormazioneContinua/ConvegnoFinaleGiugno2018/ReportConclusivoAagroalimentar eGiugno2018.pdf. [Accessed 6 August 2019].

Hącia E, Łapko A (2017) Territorial cooperation for the development of nautical tourism in the Southern Baltic Rim. DIEM: Dubrovnik International Economic Meeting 3(1): 780-792.

Ismea (2018) Rapporto sulla competitività dell'agroalimentare Italiano, Retrieved from http://www.ismea.it/flex/cm/pages/ServeAttachment.php/L/IT/D/a\%252Ff\%252F4 \%252FD.851eeb695cc245d68b89/P/BLOB\%3AID\%3D10303/E/pdf. [Accessed 6 August 2019].

Jolić N, Perko N, Kavran Z (2011) Development of Nautical Tourism: Islands Development Motivator . In Coastal Cities 2019, WIT Transactions on Ecology and the Environment, vol 149.

Kovacic M, Favro S, Mezak V (2016) Construction of nautical tourism ports as an incentive to local development. Environmental Engineering and Management Journal 15(2): 395-403. ISSN 1843-3707.

Magliulo A (2016) Cyber Security and Tourism Competitiveness. European Journal of Tourism, Hospitality and Recreation 7(2): 128-134.

Mikulić J, Krešić D, Kožić I (2015) Critical factors of the maritime yachting tourism experience: an impact-asymmetry analysis of principal components. Journal of Travel \& Tourism Marketing 32(1): S30-S41. DOI: 10.1080/10548408.2014.981628.

Pagetti F, Ietri D (2019) Inner Areas/periferie metropolitan e differenze con le Internal Areas. In M Prezioso (ed) Quale Territorial Impact Assessment della Coesione Territoriale nelle regioni italiane. La concettualizzazione del problema, 205-211. Bologna: Pàtron.

Panai E (2018) A Cyber Security Framework for Independent Hotels. Proceedings $4^{\text {th }}$ EATSA - FRANCE 2018, Challenges of tourism development, 145-152.

Panai E, Łapko A, Mariotti G, Camerada V, Strulak-Wójcikiewicz R (2019) Data security as the basis for the operation of online travel platforms on the example of platforms dedicated to nautical tourism: cyber analysis and geographical impacts. Proceedings 5th EATSA TURKEY 2019 Building Competitive Advantage of Euro-Asian Tourism.

Prezioso M (2015) Blue Growth cross-border evidence: quale resilienza all'organizzazione economica policentrica terra-mare. In M Pinto Commenale (ed) La continuità territorial della Sardegna, 89-116. Roma: Aracne

Prezioso M (2019) Quale Territorial Impact Assessment della Coesione Territoriale nelle regioni italiane. La concettualizzazione del problema. Bologna: Pàtron. 
Ries E (2011) The Lean Startup: How Today's Entrepreneurs Use Continuous Innovation To Create Radically Successful Businesses. New York: Crown Publishing Group. ISBN 10: 0307887898.

Saarinen J (2006) Traditions of sustainability in tourism studies. Annals of Tourism Research 33(4): 1121-1140

Scrofani L, Novembre C, Di Bella A, Ruggiero L (2019) Inner Areas/Periferie metropolitan e differenze con le Inner Areas, In Prezioso, M., 2019. Quale Territorial Impact Assessment della Coesione Territoriale nelle regioni italiane. La concettualizzazione del problema, 212-223. Bologna: Pàtron.

World Bank (2017) The Potential of the Blue Economy. Washington: World Bank Group. Retrieved from https://bit.ly/2PpNyfV. [Accessed 7 March 2019]. 